\title{
Analisis Karakteristik Dewan Direksi dan Kepemilikan Terhadap Kinerja Keuangan Perusahaan Keluarga
}

\author{
Santi Yopie \\ Universitas Internasional Batam \\ Santi.yopie@uib.ac.id \\ Elen Andriani \\ Universitas Internasional Batam \\ amdrianielen@gmail.com
}

\begin{abstract}
Abstrak
Penelitian ini bertujuan untuk mengidentifikasi hubungan karakteristik dewan dan kepemilikan terhadap kinerja perusahaan keluarga di Bursa Efek Indonesia. Variabel independen yang digunakan dalam penelitian ini adalah ukuran anggota dewan, frekuensi rapat anggota dewan, indenpendensi anggota dewan, kepemilikan institusional, kepemilikan orang asing, dan konsentrasi kepemilikan. Variabel dependen yang digunakan adalah kinerja keuangan. Metode penelitian ini menggunakan regresi panel dengan menggunakan data sekunder yang diperoleh dari laporan tahunan oleh perusahaan keluarga di BEI yang terdaftar pada periode 2015-2019. Hasil uji dalam penelitian ini menunjukkan bahwa direktur independen dan umur perusahaan memberikan pengaruh signifikan positif terhadap ROA. Sedangkan, kepemilikan asing dan kepemilikan terkonsentrasi yang menghasilkan hubungan signifikan negatif terhadap Tobin's Q. Semakin banyak jumlah anggota dewan direksi independen maka akan semakin baik pula kinerja keuangan perusahaan dalam hal ini perusahaan keluarga yang terdaftar di BEI. Hal ini dikarenakan pengambilan keputusan yang independen dan professional akan mendorong peningkatan kinerja perusahaan. Pemantauan atas kegiatan yang dilakukan manajemen akan lebih ketat sehingga tidak akan tercipta oportunisme bagi manajemen dalam melakukan penyelewengan. Selain itu, kepemilikan asing memberikan efek negatif terhadap kinerja perusahaan keluarga. Konsentrasi kepemilikan akan mengurangi kinerja perusahaan karena konsentrasi kepemilikan cenderung mengedepankan kepentingan kelompok tertentu. Hal ini dinilai dapat menjadi pemicu conflict of interest baik antar pemegang saham, dan juga manajemen dengan pemegang saham yang dapat memperburuk kinerja keuangan perusahaan kecil.
\end{abstract}

Kata Kunci Kinerja keuangan, karakteristik dewan, karakteristik kepemilikan, perusahaan keluarga

\section{PENDAHULUAN}

Dalam sebuah bisnis dan perusahaan, kinerja keuangan merupakan suatu hal yang penting mengingat hal ini dapat mempengaruhi keberlangsungan dari bisnis itu sendiri. Tidak terbatas pada perusahaan dengan industri tertentu maupun kepemilikan tertentu, seluruhnya tentu harus memperhatikan kinerja keuangan yang dimilikinya. Perusahaan dengan kepemilikan keluarga mulai bermunculan di jajaran daftar perusahaan listed di Bursa Efek Indonesia (BEI). Berbagai konflik dan isu yang bermunculan terkait tata kelola perusahaan keluarga menyebabkan 
munculnya pertanyaan mengenai dampaknya terhadap kinerja keuangan serta keberlangsungan dari perusahaan dengan kepemilikan keluarga.

Dasar tujuan didirikannya sebuah bisnis dan perusahaan adalah memperoleh keuntungan yang mana hal tersebut pada akhirnya akan memperkaya pemilik perusahaan (Saidat, 2019). Keuntungan yang sudah diperoleh tentunya harus dikelola dengan baik agar dapat menjamin keberlangsungan perusahaan kedepannya, dan menjamin agar perusahaan dapat tetap mencapai keuntungan dan dapat menambah nilai perusahaan untuk periode berikutnya (Sheikh, 2013). Evaluasi terhadap pengelolaan yang berlangsung menjadi satu hal yang penting dalam mencapai suatu tujuan, Al-Saidi \& Al-Shammari (2015) mengidentifikasi bahwa kinerja keuangan perusahaan dapat menjadi suatu tolak ukur untuk evaluasi dalam menilai pengelolaan yang telah jalani oleh suatu perusahaan.

Kinerja keuangan perusahaan menjadi hal yang penting untuk diperhatikan mengingat hal ini berhubungan secara langsung dengan keberlangsungan dari perusahaan (Palaniappan, 2017). Penting untuk mengetahui apa saja yang dapat mempengaruhi kinerja keuangan dari perusahaan, Assenga, Aly \& Hussainey (2018) menyatakan bahwa tata kelola mampu memberikan pengaruh terhadap kinerja keuangan suatu perusahaan. Penerapan tata kelola yang baik dan tepat tentu akan mampu meningkatkan kinerja keuangan dari perusahaan, karena tata kelola dinilai sebagai fungsi penggerak utama dalam pengelolaan yang dilakukan oleh perusahaan (Ullah et al., 2015). Banyaknya segmentasi dalam tata kelola perusahaan menjadi satu hal yang perlu pertimbangkan dalam meneliti bagaimana tata kelola mampu mempengaruhi kinerja keuangan perusahaan, Haldar, Mishra \& Dash (2016) memaparkan segmen tata kelola perusahaan terkait karakteristik perusahaan dan juga struktur kepemilikan merupakan hal yang memiliki hubungan cukup erat dengan pengelolaan dari suatu perusahaan karena keduanya berhubungan secara langsung dengan operasional dari perusahaan.

Beberapa kasus terkait penerapan tata kelola perusahaan telah tercatat di Indonesia dan sebagain darinya merupakan perusahaan keluarga, seperti kasus perusahaan blue bird pada tahun 2004, perusahaan Grup Sinar Mas pada tahun 2020, perusahaan penerbangan Garuda Indonesia pada tahun 2019, PT Katarina Utama Tbk pada tahun 2012, dan PT Asuransi Jiwasraya Persero pada tahun 2019. Penerapan tata kelola perusahaan menjadi hal yang perlu dipantau oleh suatu perusahaan karena hal tersebut secara langsung mempengaruhi hal vital yakni kinerja keuangan dari perusahaan Dwivedi \& Jain (2005).

Penelitian ini dirancang dengan pertimbangan bahwa banyaknya kasus yang bermunculan terkait penerapan tata kelola perusahaan yang berdampak pada kinerja keuangan dari perusahaan, serta tidak konsistennya hasil yang diberikan oleh penelitian terdahulu terkait hubungan antara tata kelola dan kinerja keuangan perusahaan. Dengan hal itu maka tujuan utama dari penelitian ini yakni mengidentifikasi pengaruh yang diberikan oleh tata kelola perusahaan khususnya terkait karakteristik dewan direksi dan struktur kepemilikan terhadap seperti ukuran dewan direksi, dewan direksi independen, rapat dewan direksi, kepemilikan asing, institusional dan terkonsentrasi terhadap kinerja keuangan perusahaan.

\section{LANDASAN TEORI}

Agyei-Mensah (2018) telah melaksanakan pengujian yang secara empiris mengenai hubungan yang terdapat antara direktur independen, ukuran dewan direksi, kepemilikan institusional, board gender diversity, konsentrasi kepemilikan, likuiditas, keterlambatan pelaporan keuangan dan ukuran komite audit terhadap kinerja keuangan perusahaan. Dalam periode yang sama Assenga et al. (2018) melakukan riset serupa terkait pengaruh tata kelola perusahaan terhadap kinerja keuangan namun dengan terfokus pada segmentasi terkait dewan direksi seperti direktur 
independen, ukuran dewan direksi, CEO duality, board gender diversity, keahlian dewan direksi serta direktur asing.

Penelitian terkait kinerja keuangan dan tata kelola perusahaan juga telah dilakukan sebelumnya oleh Al-Saidi \& Al-Shammari (2015) dengan berfokus pada struktur kepemilikan diantaranya kepemilikan pemerintah, institusional, keluarga, dan terkonsentrasi. Namun penelitian ini dikembangkan kembali oleh Kao et al (2019) dengan menambahkan direktur independen, ukuran dewan direksi, struktur dewan direksi, CEO duality, dan kepemilikan keluarga. Jauh ditahun sebelumnya, Ehikioya (2009) ternyata juga telah melakukan riset serupa namun dengan beberapa variabel yang berbeda seperti adanya variabel kepemilikan oleh dewan direksi dan board relative.

Pada tahun 2016 terdapat beberapa penelitian yang dilakukan terhadap kinerja keuangan dan tata kelola perusahaan seperti yang telah dilakukan oleh Arora \& Sharma (2016) yang memadukan tata kelola terkait dewan direksi dan struktur kepemilikan seperti CEO duality, direktur independen, ukuran dewan direksi, rapat dewan direksi serta kepemilikan institusional. Haldar $e t$ al. (2016) juga melaksanakan riset yang sama namun dengan tambahan jenis kelamin dewan direksi, dan kepemilikan manajemen. Eksplorasi mengenai pengaruh yang diberikan tata kelola terhadap kinerja keuangan perusahaan bertambah dengan penelitian yang dilakukan oleh Malik \& Makhdoom (2016) dengan menambahkan kompensasi CEO sebagai salah satu variabel independen dalam penelitiannya.

\section{Kinerja Keuangan Perusahaan}

Tingkat efisiensi dari suatu perusahaan dalam memanfaatkan serta mengelola seluruh sumber daya yang dimilikinya dalam mendapatkan keuntungan dapat secara subjektif diukur menggunakan tingkat kinerja keuangan perusahaan (Ullah et al., 2015). Hal ini menjadikan kinerja keuangan menjadi suatu prioritas bagi para pemegang saham serta calon investor dalam menilai suatu perusahaan yang telah dan akan didanai Purwanto et al. (2018).

Kemampuan dari tingkat kinerja keuangan suatu perusahaan tidak hanya berkaitan dengan situasi saat ini namun juga berkenaan dengan kondisi masa mendatang (Darko et al., 2016). Hasil kinerja keuangan dapat dijadikan sebagai dasar dalam menganalisis Tindakan preventif dalam rangka pengambilan keputusan Waheed \& Malik (2019). Rahman et al (2015) juga menambahkan bahwa hubungan yang erat ditemukan dalam kinerja keuangan perusahaan dengan keberlangsungan bisnis yang dijalankannya, semakin baik kinerja keuangan yang dimiliki perusahaan maka akan memberikan jaminan terhadap keberlangsungan bisnis usaha yang dijalankannya.

\section{Pengaruh Ukuran Dewan Direksi terhadap Kinerja Keuangan Perusahaan}

Dewan direksi merupakan pilihan dan orang yang secara langsung dipilih oleh pemegang saham dalam mengemban tugas sebagai fungsi pengawasan dan pengendalian operasional perusahaan (Sheikh et al., 2013). Dalam Peraturan Otoritas Jasa Keuangan nomor 33/POJK.04/2014 telah ditetapkan bahwa setiap perusahaan paling tidak harus memiliki 2 dewan direksi yang menjabat. Jumlah dewan direksi yang banyak akan memaksimalkan efektifitas dari pengawasan yang dilakukan, serta mempunyai keahlian dengan tingkat kolektifitas yang tinggi sehingga hal ini dapat memberikan dampak yang baik pada kinerja keuangan perusahaan Agyei-Mensah (2018).

Tshipa et al. (2018); Ujunwa (2012); dan Assenga et al. (2018) dalam penelitian sebelumnya mendukung pernyataan tersebut. Sementara Allam (2018) justru tidak menemukan adanya hubungan yang signifikan antara ukuran dewan direksi dan kinerja keuangan perusahaan.

H1: Ukuran dewan direksi berpengaruh signifikan positif terhadap kinerja keuangan perusahaan Pengaruh Frekuensi Rapat Dewan Direksi terhadap Kinerja Keuangan Perusahaan Dalam Peraturan Otoritas Jasa Keuangan nomor 33/POJK.04/2014 telah ditetapkan bahwa perusahaan wajib menyelenggarakan rapat dewan direksi secara rutin paling tidak satu kali dalam 
sebulan. Frekuensi rapat yang dilakukan dewan direksi dicantumkan dalam laporan tahunan yang di publikasikan.

Frekuensi dan intensitas rapat direksi yang tinggi dapat membantu dalam percepatan penyelesaian masalah operasional terkait kinerja perusahaan, serta mampu meningkatkan pemantauan terhadap manajemen yang mana hal ini akan membantu meningkatkan kinerja keuangan perusahaan Malik \& Makhdoom (2016).

Arora \& Sharma (2016); Malik \& Makhdoom (2016); Chaudhary \& Gakhar (2018); dan Mishra \& Kapil (2018) mendukung pendapat tersebut dalam penelitian yang dilakukannya, sedangkan (Z, Rohman \& Zulaikha, 2018) justru tidak menemukan adanya hubungan yang signifikan antara rapat direksi dan kinerja keuangan perusahaan.

\section{H2: Frekuensi rapat dewan direksi berpengaruh signifikan positif terhadap kinerja keuangan perusahaan}

\section{Pengaruh Dewan Direksi Independen terhadap Kinerja Keuangan Perusahaan}

Dewan direksi independen merupakan anggota dari jajaran direksi namun tidak terafiliasi secara langsung dengan perusahaan (Tshipa et al., 2018). Dewan direksi independen mampu memegang peran kunci untuk pemantauan terhadap manajemen dengan fungsi serta wewnang yang dimilikinya Haldar et al. (2016).

Jumlah dewan direksi independen mampu memberikan pengaruh terhadap kinerja keuangan suatu perusahaan melalui peran yang dijalankannya, yakni dengan adanya direktur independen maka akan lebih mengarahkan pengawasan terhadap manajemen yang terstruktur dan obektif (Tshipa et al., 2018). Pemantauan atas kegiatan yang dilakukan manajemen akan lebih ketat sehingga tidak akan tercipta oportunisme bagi manajemen dalam melakukan penyelewengan (Darko et al., 2016).

Pendapat terkait pengaruh tersebut searah dengan hasil dari penelitian yang telah dilakukan oleh Saidat et al. (2019); Palaniappan (2017); Ahmed Haji (2014); Malik \& Makhdoom (2016); Haldar et al. (2016); Ullah et al. (2015); dan Mishra \& Kapil (2018). Berlawanan dengan itu, AgyeiMensah (2018); Purwanto et al. (2018); Rahman et al. (2015); dan Tshipa et al. (2018) justru menemukan hasil bahwa direktur independen memberikan pengaurh yang signifikan negatif terhadap kinerja keuangan perusahaan.

\section{H3: Direktur independen berpengaruh signifikan positif terhadap kinerja keuangan perusahaan}

\section{Pengaruh Konsentrasi Kepemilikan terhadap Kinerja Keuangan Perusahaan}

Kepemilikan terkonsentrasi pada umumnya diterapkan oleh negara berkembang (Aluchna \& Kaminski, 2017). Kepemilikan terkonsetrasi dikategorikan berdasarkan persentase kepemilikan saham yang cukup signifikan yang hanya oleh beberapa pihak (Berezinets et al., 2017).

Perbandingan yang cukup signifikan menghasilkan ketimpangan yang cukup tinggi antara pemegang saham dengan kepemilikan terkonsentrasi dan kepemilikan dalam skala kecil (Sheikh et al., 2013). Hal ini dinilai dapat menjadi pemicu conflict of interest bai kantar pemegang saham, dan juga manajemen dengan pemegang saham yang dapat mempengaruhi memburuknya kinerja keuangan perusahaan kecil (Darko et al., 2016).

Hal ini sejalan dengan hasil penelitian yang telah dilakukan oleh Saidat et al. (2019); AgyeiMensah (2018); Waheed \& Malik (2019); dan Al-Saidi \& Al-Shammari (2015) namun bertolak belakang dengan Sheikh et al. (2013); Ehikioya (2009); Kao et al. (2019) yang justru menemukan 
adanya hubungan yang signifikan positif antara kepemilikan terkonsentrasi dengan kinerja keuangan perusahaan.

H4: Kepemilikan terkonsentrasi berpengaruh signifikan negatif terhadap kinerja keuangan perusahaan

\section{Pengaruh Kepemilikan Institusional terhadap Kinerja Keuangan Perusahaan}

Kepemilikan institusional diidentifikasikan sebagai jumlah saham yang dimiliki oleh badan maupun institusi yang biasanya berkedudukan lokal sewilayah dengan perusahaan (Ahmed Haji, 2014).

Sebagian besar institusi maupun badan yang menginvestasikan modalnya pada perusahaan lain ini pada dasarnya memiliki bisnis dan usaha utama yang dikelolanya (Arouri et al., 2014). Dan justru, banyak ditemukan bahwa bisnis usaha utama yang dimiliki investor institusional lebih besar dan bonafide dibandingkan perusahaan tempat ditanamkannya modal Dwivedi \& Jain (2005). Hal ini tentu menjadi pemicu tidak fokusnya pemegang saham institusional dalam mengelola dan memantau kinerja dari perusahaan yang didanai, sehingga hal ini akan menurunkan fungsi pengawasan yang mana akan berdampak pada menurunnya kinerja keuangan perusahaan yang didanai (Arora \& Sharma, 2016).

Agyei-Mensah (2018); Ahmed Haji (2014); Arora \& Sharma (2016); Waheed \& Malik (2019); Dwivedi \& Jain (2005); dan Arouri et al. (2014) mendukung pendapat ini dengan hasil penelitian yang telah dilakukannya. Selain itu, terdapat pula Ullah et al. (2015); Kao et al. (2019); dan Z et al. (2018) yang justru mengemukakan hasil berupa hubungan yang signifikan positif antara kepemilikan institusional dengan kinerja keuangan perusahaan.

\section{H5: Kepemilikan institusional berpengaruh signifikan negatif terhadap kinerja keuangan perusahaan}

\section{Pengaruh Kepemilikan Asing terhadap Kinerja Keuangan Perusahaan}

Jumlah saham yang dimiliki oleh perorangan maupun badan dari wilayah dan kewarganegaraan asing merupakan kategori dari kepemilikan asing (Saidat et al., 2019). Banyak pertimbangan dari para investor asing dalam memutuskan untuk mendanai perusahaan lokal (Kao et al., 2019).

Pola pikir serta gagasan lebih maju yang dimiliki oleh investor asing seperti kemampuan monitoring yang lebih transparan, Teknik pengelolaan yang terstruktur akan mampu meningkatkan kinerja keuangan perusahaan menjadi lebih baik Abor \& Biekpe (2007).

Kao et al. (2019); Saidat et al. (2019); dan Abor \& Biekpe (2007) mendukung pernyataan tersebut dengan hasil penelitian yang dihasilkannya. Sedangkan Dwivedi \& Jain (2005) dan Arouri et al. (2014) justru menemukan bahwa kepemilikan asing berpengaruh signifikan negatif terhadap kinerja keuangan perusahaan.

\section{H6: Kepemilikan asing berpengaruh signifikan positif terhadap kinerja keuangan perusahaan}

\section{METODOLOGI PENELITIAN}

Sifat dari penelitian dasar yang dilakukan ini adalah komparatif dan kuantitatif (Indriantoro \& Supomo, 2015). Metode penelitian ini menggunakan regresi data panel dengan alat uji berupa eviews. Laporan tahunan serta laporan keuangan yang telah di audit merupakan sumber data yang dikelola dalam penelitian ini, yang dimana laporan-laporan tersebut didapatkan dari publikasi pada situs BEI. Cakupan rentang waktu data yang dijadikan sampel yakni dari tahun 2015 sampai dengan 2019. 
Objek penelitian ini adalah perusahaan keuarga. Kriteria mengenai perusahaan keluarga adalah CEO perusahaan merupakan pendiri dari perusahaan atau penerus dari CEO mempunyai hubungan darah maupun pernikahan, setidaknya ada dua orang anggota keluarga yang ikut serta dalam manajemen, serta direksi dari pihak keluarga mempunyai paling tidak $20 \%$ saham di perusahaan merupakan beberapa kriteria dari perusahaan agar dapat dikategorikan sebagai perusahaan keluarga (Afza Amran \& Che Ahmad, 2009).

Kinerja keuangan perusahaan menjadi variabel dependen dalam penelitian yang dilakukan ini, yang dinilai dengan menggunakan dua pengukuran yakni persentase dari Return on Asset (ROA) dan Tobins'Q Saidat et al., (2019). Variabel independen dalam penelitian ini menggunakan pengukuran sebagaimana dipaparkan pada Tabel 1 berikut ini:

Tabel 1. Definisi Pengukuran Variabel Independen

\begin{tabular}{|l|l|}
\hline \multicolumn{1}{|c|}{ Variabel } & \multicolumn{1}{c|}{ Pengukuran } \\
\hline $\begin{array}{l}\text { Ukuran Anggota Dewan Direksi } \\
\text { (BSIZE) }\end{array}$ & $\begin{array}{l}\text { Total anggota yang menjabat direksi di perusahaan pada } \\
\text { periode tertentu }\end{array}$ \\
\hline $\begin{array}{l}\text { Frekuensi Rapat Dewan Direksi } \\
\text { (BM) }\end{array}$ & $\begin{array}{l}\text { Proporsi rapat yang dilaksanakan oleh direksi dalam 1 } \\
\text { tahun }\end{array}$ \\
\hline Dewan Direksi Independen (IND) & $\begin{array}{l}\text { Proporsi dewan direksi independen yang menjabat di } \\
\text { perusahaan }\end{array}$ \\
\hline $\begin{array}{l}\text { Kepemilikan Terkonsentrasi } \\
\text { (CONCOWN) }\end{array}$ & $\begin{array}{l}\text { Proporsi saham yang diperoleh lebih dari 5\% / total } \\
\text { saham outstanding }\end{array}$ \\
\hline $\begin{array}{l}\text { Kepemilikan } \\
\text { (INSOWN) }\end{array}$ & $\begin{array}{l}\text { Proporsi saham yang diperoleh oleh institusi / total } \\
\text { saham outstanding }\end{array}$ \\
\hline Kepemilikan Asing (FOREIGN) & $\begin{array}{l}\text { Proporsi saham yang diperolej oleh investor asing / total } \\
\text { saham outstanding }\end{array}$ \\
\hline Ukuran Perusahaan (FSIZE) & Logaritma total asset \\
\hline Umur Perusahaan (AGE) & Usia perusahaan sampai pada periode tahun data sampel \\
\hline Leverage (LEV) & Total utang/total aset \\
\hline
\end{tabular}

Sumber: Data sekunder diolah (2020)

\section{HASIL PENELITIAN}

Dalam penelitian ini telah menggunakan sampel sebanyak 98 perusahaan keluarga selama periode 2015-2019 dengan total 490 data. Sesuai hasil uji deskriptif, menunjukan bahwa rata- rata perusahaan keluarga memiliki minimal 2 direktur dan rata-rata aktif dalam menjalankan pertemuan rapat anggota direksi minimal 12 kali dalam setahun. Namun, masih terdapat perusahaan yang tidak memiliki direktur independen. Rata-rata perusahaan keluarga yang dijadikan sampel ini tidak dimiliki oleh kepemilikan asing dan cenderung dimiliki oleh kepemilikan orang lokal. Dilihat dari umur perusahaan keluarga rata-rata adalah lebih dari 10 tahun. Signifikansi dari pengaruh tiap variabel independen maupun variable kontrol terhadap kinerja keuangan perusahaan yang merupakan variabel dependen dapat diuji dengan menggunakan uji t. Hasil dari pengujian uji t dengan menggunakan pengukuran ROA dipaparkan dalam Tabel 2 dan Tobins'Q pada Tabel 3.

Tabel 2. Hasil Uji t Menggunakan ROA

\begin{tabular}{l|r|r|l}
\hline \multicolumn{1}{c|}{ Variabel } & Koefisien & Prob. & Kesimpulan \\
\hline C & 0.29 & 0.13 & \\
\hline BSIZE & -0.01 & 0.08 & H1 ditolak \\
\hline BM & -0.00 & 0.34 & H2 ditolak \\
\hline
\end{tabular}


Sumber: Data sekunder diolah (2020)

\begin{tabular}{l|r|r|l}
\hline IND & 0.02 & 0.00 & H3 diterima \\
\hline INSOWN & -0.00 & 0.97 & H4 ditolak \\
\hline FOREIGN & 0.03 & 0.27 & H5 ditolak \\
\hline CONCOWN & 0.00 & 0.96 & H6 ditolak \\
\hline AGE & 0.00 & 0.05 & H7 diterima \\
\hline LEV & 0.01 & 0.07 & H8 ditolak \\
\hline FSIZE & -0.04 & 0.09 & H9 ditolak \\
\hline
\end{tabular}

Dari pemaparan hasil pada Tabel 10 dapat diketahui bahwa terdapat 2 dari 9 variabel yang mampu mempengaruhi kinerja keuangan perusahaan keluarga secara signifikan. Direktur independen dan umur perusahaan memberikan pengaruh signifikan positif terhadap variabel dependen diukur dengan menggunakan ROA. dan kedua hasil tersebut mendukung hipotesis penelitian ini. Rumus untuk persamaan regresi dari pengujian ini yakni:

ROA $=0,2992-0,0055 \mathrm{BS}-0,0003 \mathrm{BM}+0,0215 \mathrm{ID}-0,0008$ INSOWN + 0,0294 FOROWN $+0,0019$ CONCOWN + 0,0029 AGE $+0,0137 \mathrm{LEV}-0,0389$ FSIZE $+e$

Tabel 3. Hasil Uji t Menggunakan Tobins' $Q$

\begin{tabular}{l|r|r|l}
\hline \multicolumn{1}{c|}{ Variabel } & Koefisien & Prob. & Kesimpulan \\
\hline C & 10.26 & 0.19 & \\
\hline BSIZE & -0.07 & 0.61 & H1 ditolak \\
\hline BM & 0.02 & 0.27 & H2 ditolak \\
\hline IND & -0.64 & 0.03 & H3 ditolak \\
\hline INSOWN & 0.68 & 0.52 & H4 ditolak \\
\hline FOREIGN & -3.58 & 0.00 & H5 ditolak \\
\hline CONCOWN & -4.15 & 0.00 & H6 diterima \\
\hline AGE & 0.05 & 0.38 & H7 ditolak \\
\hline LEV & 0.36 & 0.24 & H8 ditolak \\
\hline FSIZE & -0.81 & 0.37 & H9 ditolak \\
\hline
\end{tabular}

Sumber: Data sekunder diolah (2020)

Untuk pengujian kedua yakni menggunakan pengukuran Tobins'Q pada variabel dependen penelitian ini. Hasil yang diberikan yaitu terdapatnya 3 variabel yang secara signifikan mempengaruhi kinerja keuangan perusahaan. Ketiga variabel tersebut adalah direktur independen, kepemilikan asing dan kepemilikan terkonsentrasi yang menghasilkan hubungan signifikan negatif. Sementara itu, dari 3 hasil tersebut hanya ada 1 yang mendukung hipotesis penelitian ini yaitu pada variabel konsentrasi kepemilikan. Perumusan dari persamaan regresi untuk hasil pengujian ini yaitu:

Tobins'Q $=10,263-0,0673 \mathrm{BS}+0,0176 \mathrm{BM}-0,6430 \mathrm{ID}+0,6764$ INSOWN $-3,5801$ FOROWN $-4,1498$ CONCOWN + 0,0545 AGE + 0,3619 LEV - 0,8060 FSIZE $+e$

\section{KESIMPULAN}

Tujuan dilakukannya penelitian ini adalah dalam rangka melakukan pengujian dampak dari karakteristik dewan direksi dan karakteristik dari kepemilikan terhadap kinerja keuangan perusahaan keluarga. Hasil penelitian mengemukakan bahwa hipotesis $\mathrm{H}_{2}$, dan $\mathrm{H}_{6}$ dapat diterima karena dewan direksi yang independen dan konsentrasi kepemilikan mempunyai pengaruh signifikan terhadap kinerja perusahaan. Hasil penelitian atas $\mathrm{H}_{1}, \mathrm{H}_{3}, \mathrm{H}_{4}$, dan $\mathrm{H}_{5}$ ditolak karena membuktikan bahwa tidak mempunyai hubungan pengaruh yang signifikan. Ukuran dewan, jumlah frekuensi rapat, dan kepemilikan institusional tidak mempunyai pengaruh yang signifikan terhadap kinerja keuangan. Hal ini dikarenakan rata-rata perusahaan keluarga diduduki oleh 
anggota keluarga pada jajaran direksi, sehingga keaktifan direksi dan jumlah direksi tidak dapat memberikan keputusan yang independen melainkan lebih memihak kepada kelompok mayoritas tertentu. Hasil dari pengujian dalam penelitian ini menemukan bahwa direktur independen dan umur perusahaan mempunyai dampak signifikan positif terhadap kinerja keuangan perusahaan yang diukur menggunakan ROA, yang artinya semakin banyak jumlah dewan direksi independen maka akan semakin baik pula kinerja keuangan perusahaan dalam hal ini perusahaan keluarga yang terdaftar di BEI, dan begitu pula dengan umur perusahaan. Semakin tua umur dari perusahaan, maka semakin tinggi pula kinerja keuangan perusahaan. Pemantauan atas kegiatan yang dilakukan manajemen akan lebih ketat sehingga tidak akan tercipta oportunisme bagi manajemen dalam melakukan penyelewengan. Selain itu, ditemukan juga bahwa terdapat hubungan signifikan negatif kepemilikan asing dan kepemilikan terkonsentrasi terhadap kinerja keuangan perusahaan yang diukur dengan menggunakan Tobins' $Q$. Hal ini dinilai dapat menjadi pemicu conflict of interest baik antar pemegang saham, dan juga manajemen dengan pemegang saham yang dapat mempengaruhi memburuknya kinerja keuangan perusahaan kecil. Hasil dari penelitian ini dapat dijadikan dasar implikasi oleh calon investor dan pemegang saham untuk menilai kinerja keuangan dari perusahaan yang dijadikan tempat berinvestasi. Para calon investor dan pemegang saham dapat memperhatikan jumlah direktur independen serta umur dari perusahaan yang memiliki pengaruh signifikan positif terhadap kinerja keuangan. Serta perlu memperhatikan komposisi kepemilikan asing dan kepemilikan terkonsentrasi yang dimiliki perusahaan yang mana berpengaruh signifikan negatif terhadap kinerja keuangan perusahaan. Ukuran dewan direksi independen yang menjabat di perusahaan dapat menjadi hal yang perlu diperhatikan bagi pihak manajemen dikarenakan memiliki pengaruh signifikan terhadap kinerja keuangan perusahaan yang dikelola. Selain itu hal-hal terkait keberadaan pemegang saham asing dan terkonsentrasi perlu menjadi hal dipertimbangkan dalam perusahaan dengan kepemilikan keluarga karena memiliki pengaruh signifikan negatif terhadap kinerja keuangan perusahaan.

\section{DAFTAR PUSTAKA}

Abor, J., \& Biekpe, N. (2007). Corporate governance, ownership structure and performance of SMEs in Ghana: Implications for financing opportunities. Corporate Governance, 7(3), 288-300.

Afza Amran, N., \& Che Ahmad, A. (2009). Family Business, Board Dynamics and Firm Value: Evidence from Malaysia. Journal of Financial Reporting and Accounting, 7(1), 53-74.

Agyei-Mensah, B. K. (2018). Impact of corporate governance attributes and financial reporting lag on corporate financial performance. African Journal of Economic and Management Studies, 9(3), 349-366.

Ahmed Haji, A. (2014). The relationship between corporate governance attributes and firm performance before and after the revised code: Some Malaysian evidence. International Journal of Commerce and Management, 24(2), 134-151.

Al-Saidi, M., \& Al-Shammari, B. (2015). Ownership concentration, ownership composition and the performance of the Kuwaiti listed non-financial firms. International Journal of Commerce and Management, 25(1), 108-132.

Allam, B. S. (2018). The impact of board characteristics and ownership identity on agency costs and firm performance: UK evidence. Corporate Governance (Bingley), 18(6), 1147-1176.

Aluchna, M., \& Kaminski, B. (2017). Ownership structure and company performance: a panel study from Poland. Baltic Journal of Management, 12(4), 485-502.

Arora, A., \& Sharma, C. (2016). Corporate governance and firm performance in developing countries: evidence from India. Corporate Governance (Bingley), 16(2), 420-436.

Arouri, H., Hossain, M., \& Badrul Muttakin, M. (2014). Effects of board and ownership structure on corporate performance. Journal of Accounting in Emerging Economies, 4(1), 117-130.

Assenga, M. P., Aly, D., \& Hussainey, K. (2018). The impact of board characteristics on the financial performance of Tanzanian firms. Corporate Governance (Bingley), 18(6), 10891106. 
Chaudhary, N., \& Gakhar, K. (2018). Corporate Governance and Financial Performance with a Perspective on Board Size and Frequency of Board Meetings: Empirical Evidence from India. Journal of Applied Management Accounting Research, 8, 21-37.

Darko, J., Aribi, Z. A., \& Uzonwanne, G. C. (2016). Corporate governance: the impact of director and board structure, ownership structure and corporate control on the performance of listed companies on the Ghana stock exchange. Corporate Governance (Bingley), 16(2), 259-277.

Dwivedi, N., \& Jain, A. K. (2005). Corporate governance and performance of Indian firms: The effect of board size and ownership. Employee Responsibilities and Rights Journal, 17(3), 161-172.

Ehikioya, B. I. (2009). Corporate governance structure and firm performance in developing economies: Evidence from Nigeria. Corporate Governance: The International Journal of Business in Society, 9(3), 231-243.

Haldar, P. ., Mishra, L., \& Dash, G. (2016). Corporate governance influence on firm' s financial performance. Srusti Management Review, 9(2), 33-40.

Handa, R. (2018). Does corporate governance affect financial performance: A study of select Indian banks. Asian Economic and Financial Review, 8(4), 478-486.

Indriantoro, N., \& Supomo. (2015). Metodologi Penelitian Bisnis untuk Akuntansi dan Manajemen. BPFE.

Kao, M. F., Hodgkinson, L., \& Jaafar, A. (2019). Ownership structure, board of directors and firm performance: evidence from Taiwan. Corporate Governance (Bingley), 19(1), 189-216.

Malik, M. S., \& Makhdoom, D. D. (2016). Does corporate governance beget firm performance in Fortune Global 500 companies? Corporate Governance (Bingley), 16(4), 747-764.

Mishra, R. K., \& Kapil, S. (2018). Board characteristics and firm value for Indian companies. Journal of Indian Business Research, 10(1), 2-32.

Palaniappan, G. (2017). Determinants of corporate financial performance relating to board characteristics of corporate governance in Indian manufacturing industry: An empirical study. European Journal of Management and Business Economics, 26(1), 67-85.

Purwanto, Suhardjanto, D., Aprilyana, W. T., \& Setiany, E. (2018). Corporate Governance and Financial Performance: A Comparative Study of South East Asia's Hospitality Industries. Review of Integrative Business and Economics Research, 7(2), 62-70.

Rahman, H. U., Ibrahim, M. Y., \& Che - Ahmad, A. (2015). Corporate governance, firm financial performance and shareholders' confidence: A proposed analysis of MCCG 2012. An International Journal Global Business \& Management Research An International Journal, 7(1), 139-147.

Saidat, Z., Silva, M., \& Seaman, C. (2019). The relationship between corporate governance and financial performance: Evidence from Jordanian family and nonfamily firms. Journal of Family Business Management, 9(1), 54-78.

Sheikh, N. A., Wang, Z., \& Khan, S. (2013). The impact of internal attributes of corporate governance on firm performance: Evidence from pakistan. International Journal of Commerce and Management, 23(1), 38-55.

Tshipa, J., Brümmer, L., Wolmarans, H., \& du Toit, E. (2018). Corporate Governance and Financial Performance in the Midst of Exogenous Shocks: A Study of Companies Listed on the Johannesburg Stock Exchange. Management Dynamics: Journal of the Southern African Institute for Management Scientists, 27(1), 20-38.

Ujunwa, A. (2012). Board characteristics and the financial performance of Nigerian quoted firms. Corporate Governance (Bingley), 12(5), 656-674.

Ullah, M., Afgan, N., Hashim, M., \& Khan, M. A. (2015). The Impact of Corporate Governance on Financial Performance of Banks Evidence from Pakistan. IOSR Journal of Business and ManagementVer. III, 17(3), 2319-7668.

Waheed, A., \& Malik, Q. A. (2019). Board characteristics, ownership concentration and firms' performance: A contingent theoretical based approach. South Asian Journal of Business Studies, 8(2), 146-165. 
Z, R. W., Rohman, A., \& . Z. (2018). The effect of good corporate governance on financial performance and net working capital turnover as a mediation variable: evidence from Indonesia Stock Exchange (IDX). Journal of Business \& Retail Management Research, 13(01), 70-81. 